\title{
Cyanobacterial blooms in stratified and destratified eutrophic reservoirs in semi-arid region of Brazil
}

\author{
ÊNIO W. DANTAS ${ }^{1,2}$, ARIADNE N. MOURA ${ }^{2}$ and MARIA DO CARMO BITTENCOURT-OLIVEIRA ${ }^{3}$ \\ ${ }^{1}$ Universidade Estadual da Paraíba, UEPB, Campus V, Centro de Ciências Biológicas e Sociais Aplicadas, CCBSA, \\ Departamento de Ciências Biológicas, Rua Horácio Trajano de Oliveira, s/n, Cristo, 58070-450 João Pessoa, PB, Brasil \\ ${ }^{2}$ Universidade Federal Rural de Pernambuco, Departamento de Biologia, Área de Botânica, \\ Rua D. Manoel de Medeiros, s/n, Dois Irmãos, 52171-030 Recife, PE, Brasil \\ ${ }^{3}$ Departamento de Ciências Biológicas, Escola Superior de Agricultura Luiz de Queiroz, \\ Universidade de São Paulo, Av. Pádua Dias, 11, 13418-900 Piracicaba, SP, Brasil \\ Manuscript received on May 31, 2010; accepted for publication on April 14, 2011
}

\begin{abstract}
This study investigated the dynamics of cyanobacteria in two deep, eutrophic reservoirs in a semi-arid region of Brazil during periods of stratification and destratification. Four collections were carried out at each reservoir at two depths at three-month intervals. The following abiotic variables were analyzed: water temperature, dissolved oxygen, $\mathrm{pH}$, turbidity, water transparency, total phosphorus, total dissolved phosphorus, orthophosphate and total nitrogen. Phytoplankton density was quantified for the determination of the biomass of cyanobacteria. The data were analyzed using CCA. Higher mean phytoplankton biomass values $\left(29.8 \mathrm{~mm}^{3} \cdot \mathrm{L}^{-1}\right)$ occurred in the period of thermal stratification. A greater similarity in the phytoplankton communities also occurred in this period and was related to the development of cyanobacteria, mainly Cylindrospermopsis raciborskii $\left(>3.9 \mathrm{~mm}^{3} . \mathrm{L}^{-1}\right)$. During the period of thermal destratification, this species co-dominated the environment with Planktothrix agardhii, Geitlerinema amphibium, Microcystis aeruginosa and Merismopedia tenuissima, as well as with diatoms and phytoflagellates. Environmental instability and competition among algae hindered the establishment of blooms more during the mixture period than during the stratification period. Thermal changes in the water column caused by climatologic events altered other physiochemical conditions of the water, leading to changes in the composition and biomass of the cyanobacterial community in tropical reservoirs.
\end{abstract}

Key words: biomass, Cylindrospermopsis raciborskii, seasonal dynamics, thermal pattern.

\section{INTRODUCTION}

The dominance of cyanobacteria in aquatic ecosystems is often associated with $\mathrm{CO}_{2}$ availability (Shapiro 1990, Caraco and Miller 1998), high temperatures (Bouvy et al. 2000, Huszar et al. 2000, Figueredo and Giani 2009, Soares et al. 2009a), low luminosity (Niklisch and Kohl 1989), high pH (Reynolds and Walsby 1975, Briand et al. 2002), high concentrations of nutrients (especially phosphorus) (Watson et al. 1997), a low N:P

Correspondence to: Ênio Wocyli Dantas

E-mail: eniowocyli@yahoo.com.br ratio (Smith 1983) and buoyancy regulation (Walsby et al. 1997). However, a large number of papers have demonstrated that the dominance of these algae occurs due to the synergism of a combination of these factors, particularly the bottom-up influence and physical changes (Briand et al. 2002, Marinho and Huszar 2002, Figueredo and Giani 2009, Soares et al. 2009a). The generalization of cause-and-effect in the understanding of the success of cyanobacteria in aquatic ecosystems is difficult, as these algae belong to an ancient, diversified group of species with often contrasting eco-physio- 
logical strategies (Marinho and Azevedo 2007). Thus, generalizations lead to divergences with regard to the cause and consequence of particular factors in the development of cyanobacteria.

There is consensus among researchers regarding the factors that best explain the dominance and blooms of cyanobacteria, such as ample nutrient availability, an increase in temperature, stratification, an increase in residence time and salinization (Paerl and Huisman 2008). However, although nutrients are an important factor, physical variables better explain changes in the composition of species in systems dominated throughout the year by cyanobacteria (Soares et al. 2009a).

Temperature exhibits vertical behavior that affects the availability of light and nutrients, and is a determinant in the seasonal dynamics of phytoplankton (Becker et al. 2009). Meteorological phenomena, such as wind and rain, play an important part in phytoplankton ecology in reservoirs (Calijuri et al. 2002) by changing the thermal pattern. The effect of temperature on the establishment of cyanobacterial blooms has been related to global warming (Bouvy et al. 1999, Briand et al. 2004, Paerl and Huisman 2008).

Different studies on the occurrence of cyanobacterial blooms under conditions of stratification and destratification reveal seasonal aspects, the influence of aeration in artificial destratification, the succession of the phytoplankton community and algal behavior under different trophic conditions of the ecosystem (Heo and Kim 2004, Antenucci et al. 2005, Bormans et al. 2005, Burford and O'Donohue 2006, Fonseca and Bicudo 2008, Benhardt et al. 2008, Chen et al. 2009). These studies stress the dominance of cyanobacteria under conditions of stratification and during the warm periods of summer.

However, divergences are encountered with regard to these findings in tropical regions. Persistent cyanobacterial blooms throughout the year are reported in shallow polymictic ecosystems or in those with a constantly isothermal water column (Bouvy et al. 1999, 2001, Crossetti and Bicudo 2008, Figueredo and Giani 2009, Bittencourt-Oliveira et al. 2011), as well as in colder periods (Soares et al. 2009b). In deep ecosystems, thermal stratification during warm months has been reported as the main cause of formation of large biomasses of cyanobacteria in reservoirs in Australia and Brazil. However, the dominance of these algae has been found to prevail in periods with a deep mixture zone (Saker and Griffiths 2001, Soares et al. 2009a).

High density and biomass of cyanobacteria have been reported for reservoirs in a semi-arid region of Brazil (Bouvy et al. 1999, 2001, Huszar et al. 2000, Chellappa and Costa 2003, Moura et al. 2007a, b, Chellappa et al. 2008, Dantas et al. 2008, von Sperling et al. 2008). However, these studies did not investigate the occurrence of cyanobacteria in relation to stratification. The aim of the present study was to investigate the composition and dynamics of plankton cyanobacteria in two deep eutrophic reservoirs (Zmax $>10 \mathrm{~m}$ ) in the semi-arid region of Brazil during periods of thermal stratification and destratification.

\section{STUDY AREA}

The Arcoverde reservoir $\left(8^{\circ} 33^{\prime} 28^{\prime \prime} \mathrm{S}\right.$ and $36^{\circ} 59^{\prime} 15^{\prime \prime} \mathrm{W}$ ) and Pedra reservoir $\left(8^{\circ} 29^{\prime} 35^{\prime \prime} \mathrm{S}\right.$ and $\left.36^{\circ} 56^{\prime} 39^{\prime \prime} \mathrm{W}\right)$ are located in the municipality of Pedra in the state of Pernambuco, Brazil (Fig. 1). The climate in this region is semi-arid, with two well-defined seasons: rainy (March to August) and dry (September to February) (Melo-Júnior et al. 2007).

The Arcoverde reservoir has an area of $2.0 \times$ $10^{6} \mathrm{~m}^{2}$, extension of $4.2 \mathrm{~km}$ and accumulation capacity of $18.8 \times 10^{6} \mathrm{~m}^{3}$, with a maximal and mean depth of $24.0 \mathrm{~m}$ and $9.4 \mathrm{~m}$, respectively. The Pedra reservoir is located upstream and has an area of $0.4 \times 10^{6} \mathrm{~m}^{2}$, extension of $1.6 \mathrm{~km}$ and a volume of $2.9 \times 10^{6} \mathrm{~m}^{3}$, with a maximal and mean depth of $15.0 \mathrm{~m}$ and $7.2 \mathrm{~m}$, respectively. These reservoirs are used for the water supply of approximately 100 thousand inhabitants (SRH 2000).

\section{MATERIALS AND METHODS}

Sampling was carried out at three-month intervals between November 2007 and August 2008, with four collections per reservoir. The collection sites were established at 200 meters from the border in the central body of each reservoir. For the determination of abiotic variables and the quantitative analysis of the cyanobacteria, water samples were collected with a Van Dorn 




Fig. 1 - Geographic location of Arcoverde and Pedra reservoirs, northeastern Brazil.

bottle at two depths: subsurface $(0.1 \mathrm{~m})$ and bottom $(1 \mathrm{~m}$ above the sediment). The depth of the bottom collection ranged from 12 to $20 \mathrm{~m}$ in the Arcoverde reservoir, and from 9 to $13 \mathrm{~m}$ in the Pedra reservoir.

In situ determinations were made of water temperature $\left({ }^{\circ} \mathrm{C}\right)$ and dissolved oxygen $\left(\mathrm{mg} . \mathrm{L}^{-1}\right)$ using an oximeter (Schott, Handylab OX1), water transparency with a Secchi disk, maximal depth using an echosounder, turbidty (NTU) with a turbidimeter (Hanna Instruments, HI 93703) and $\mathrm{pH}$ with a potenciometer (Digimed, DMPH-2). The euphotic zone (Zeu) was calculated as three times the value of the Secchi disk (Cole 1994). The mixture zone (Zmix) was determined from the profile of the temperature in the water column and was equal to maximal depth ( $\mathrm{Zmax}$ ) when there was no thermal gradient of a minimal difference of $0.5^{\circ} \mathrm{C} . \mathrm{m}^{-1}$.

The determination of total nitrogen $(\mu \mathrm{mol})$ and total phosphorus $(\mu \mathrm{mol})$ was based on the procedure described by Valderrama (1981), whereas total dissolved phosphorus $(\mu \mathrm{mol})$ and orthophosphate $(\mu \mathrm{mol})$ were determined based on the procedure described by Strickland and Parsons (1965). Carlson's Trophic Index was used for the characterization of the ecosystems (Carlson 1977). The molar TN:TP ratio was determined based on Downing and McCauley (1992). For the estimation of limitation by nutrients, TN:TP $<20$ was con- sidered for limitation by nitrogen; TN:TP > 38 was considered limitation by phosphorus (Kosten et al. 2009); [TN] $<7.0 \mu \mathrm{mol}$ was considered nitrogen limitation; and $[\mathrm{TP}]<0.1 \mu \mathrm{mol}$ was considered phosphorus limitation (Reynolds 1999).

For the taxonomic and quantitative study, aliquots of $100 \mathrm{~mL}$ were collected in duplicate with a Van Dorn bottle and preserved in acetic Lugol's solution (Bicudo and Menezes 2006). The identification of cyanobacteria was performed to the lowest possible hierarchical level with the use of specialized literature (Komárek and Anagnostidis 1989, 1999, 2005, Komárek and Cronberg 2001). Other algal divisions were identified only on the group level. Density (ind. $\mathrm{mL}^{-1}$ ) was determined with the Utermöhl method (Utermöhl 1958). Biomass $\left(\mathrm{mm}^{3} . \mathrm{L}^{-1}\right)$ was calculated from cell biovolume values ( $n=30)$ based on Hillebrand et al. (1999).

Analysis of variance (ANOVA) was used to test differences in abiotic and biotic variables $(p<0.05)$ between months of thermal stratification and destratification using the Statistica 2004 software (StatSoft, Inc., Tulsa, OK, USA). Canonical correspondence analysis (CCA) was used to assess associations between cyanobacteria and environmental variables. The matrix with biotic data was constructed only with species of cyanobacteria with biomass greater than $1 \mathrm{~mm}^{3} . \mathrm{L}^{-1}$ in at least 
one sampling month. The abiotic variables were log transformed $(x)$ and progressively reduced using the "forward selection" routine on the Canoco 4.5 program. Significance $(p<0.05)$ was tested using the Monte Carlo test, with 999 unrestricted permutations.

\section{RESULTS}

The Arcoverde and Pedra reservoirs were stratified in the dry season, and destratified in the rainy season (Fig. 2).

Nitrogen limitation (N:P ratio $<3$ and $[\mathrm{TN}]<7$ $\mu$ mol) occurred throughout the study. During thermal stratification, the reservoirs were anoxic in the hypolimnion, with neutral to alkaline $\mathrm{pH}$ and total phosphorus and orthophosphate concentrations below $8.7 \mu \mathrm{mol}$ and $2.3 \mu \mathrm{mol}$, respectively. During destratification, hypoxia occurred at the bottom, with a slightly acid to alkaline $\mathrm{pH}$, the reservoirs were deeper $(\mathrm{F}=10.79, p<0.05)$ and had greater concentrations of total phosphorus $(\mathrm{F}=$ 5.83, $p<0.05)$ and orthophosphate $(\mathrm{F}=10.41, p<$ 0.01 ). No variations were found between the periods of stratification and destratification with regard to turbidity (mean: $47.8 \pm 29.4 \mathrm{NTU}$ ) or euphotic zone (mean: $1.5 \pm 0.7 \mathrm{~m}$ ) (Table I).

Eighteen species of cyanobacteria belonging to Chroococcales, Oscillatoriales and Nostocales were identified. The phytoplankton biomass was predominantly composed of cyanobacteria, especially in the period of thermal stratification, which accounted for $92 \%$ to $97 \%$ (mean: $28.0 \pm 28.9 \mathrm{~mm}^{3} \cdot \mathrm{L}^{-1}$ ) and $63 \%$ to $87 \%$ (mean: $25.4 \pm 15.3 \mathrm{~mm}^{3} . \mathrm{L}^{-1}$ ) of the total biomass in the Arcoverde and Pedra reservoirs, respectively. During destratification, the relative biomass of cyanobacteria diminished ( $45 \%$ to $79 \%$ at Arcoverde, and $41 \%$ to $83 \%$ at Pedra reservoirs), which contributed toward the occurrence of other algae, especially diatoms at Arcoverde and phytoflagellates at Pedra reservoirs (Table II, Fig. 3).

There was a significant difference in phytoplankton biomass between the periods of stratification and destratification $(\mathrm{F}=7.94, p<0.05)$. Mean biomass values during stratification were $29.3 \pm 30.3 \mathrm{~mm}^{3} . \mathrm{L}^{-1}$ at Arcoverde and $36.0 \pm 22.5 \mathrm{~mm}^{3} \cdot \mathrm{L}^{-1}$ at Pedra reservoirs, which were respectively 5.1-fold and 4.0 -fold higher than the values found in the period of destratification.
There was a vertical variation in the distribution of the biomass during stratification $(\mathrm{F}=37.55, p<$ $0.01)$, with higher values at the subsurface $(53.8 \pm$ $19.2 \mathrm{~mm}^{3} . \mathrm{L}^{-1}$ at Arcoverde and $54.9 \pm 6.3 \mathrm{~mm}^{3} . \mathrm{L}^{-1}$ at Pedra reservoirs) (Fig. 3). In both reservoirs, $C y$ lindrospermopsis raciborskii (Woloszynska) Seenaya and Subba Raju was predominant in the period of thermal stratification, with its biomass ranging from 3.9 to $57.4 \mathrm{~mm}^{3} . \mathrm{L}^{-1}$ and significantly higher values at the subsurface $(\mathrm{F}=38.61, p<0.01)$. Merismopedia tenuissima Lemmermann $\left(0.5 \pm 0.7 \mathrm{~mm}^{3} \cdot \mathrm{L}^{-1}\right)$ and Microcystis aeruginosa (Kützing) Kützing (0.8 \pm $\left.1.8 \mathrm{~mm}^{3} . \mathrm{L}^{-1}\right)$ had biomasses greater than $1.5 \mathrm{~mm}^{3} . \mathrm{L}^{-1}$ in both reservoirs in November 2007 (Table II).

During destratification, there was a significant reduction in the biomass of $C$. raciborskii $(\mathrm{F}=10.33$, $p<0.01$ ), with values below $4.5 \mathrm{~mm}^{3} \cdot \mathrm{L}^{-1}$. Planktothrix agardhii (Gomont) Anagnostidis and Komárek was more abundant in this period, with its biomass ranging from 0.0 to $5.5 \mathrm{~mm}^{3} \cdot \mathrm{L}^{-1}$. Geitlerinema amphibium (C. Agardh) Anagnostidis $\left(0.8 \pm 0.9 \mathrm{~mm}^{3} . \mathrm{L}^{-1}\right)$ and $M$. tenuissima $\left(0.5 \pm 0.4 \mathrm{~mm}^{3} \cdot \mathrm{L}^{-1}\right)$ also had biomasses above $1 \mathrm{~mm}^{3} . \mathrm{L}^{-1}$ (Table II).

The canonical correspondence analysis confirmed the association between the abiotic variables and cyanobacterial biomass $(p<0.01)$. Axes 1 and 2 explained $72.3 \%$ of the variance in biomass. The correlation between the species and abiotic variables explained $83.7 \%$ of the canonical ordination on the first two axes (Table III).

Stratification and destratification were related to Axis 1. Sampling units related to stratification (November and February) were on the negative side of the axis, whereas those related to destratification (May and $\mathrm{Au}-$ gust) were on the positive side. C. raciborskii was inversely related to Axis 1 and was the most abundant taxon during thermal stratification. This organism was also associated to higher $\mathrm{pH}$, a greater availability of light in the epilimnion, lesser depths and lower phosphorus values. P. agardhii was directly related to the axis and was abundant under conditions that were contrary to those that favored C. raciborskii (Table III, Fig. 4).

The second axis revealed an evident vertical variation in the period of thermal stratification and demonstrated heterogeneity between sampling months in this 
${ }^{\circ} \mathrm{C}$

232425262728293031

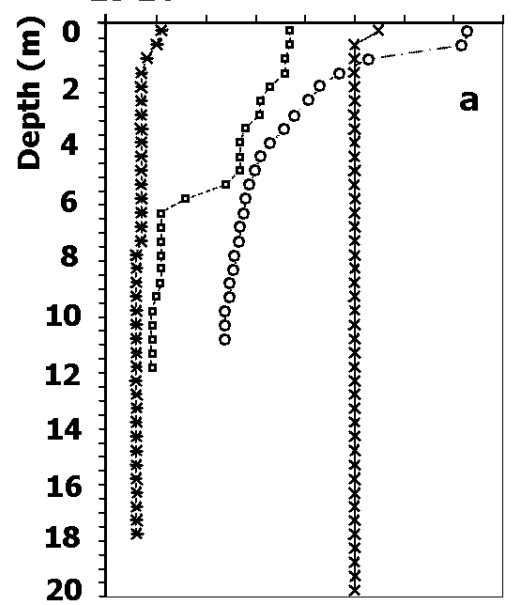

${ }^{\circ} \mathrm{C}$

232425262728293031

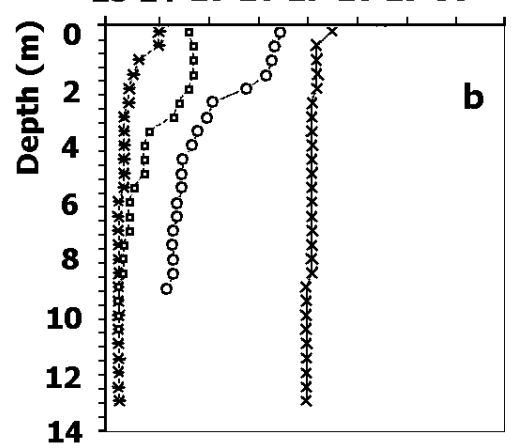

Months:

o. Feb 08 -*- Aug 08

Fig. 2 - Temperature profile in Arcoverde (a) and Pedra (b) reservoirs (Pernambuco State, Brazil) between November 2007 and August 2008; dry months: Nov 07 and Feb 08; rainy months: May 08 and Aug 08.

TABLE I

Values of variables determined at the subsurface (S) and bottom (B) of two reservoirs in the state of Pernambuco, Brazil, from November 2007 to August 2008.

\begin{tabular}{|c|c|c|c|c|c|c|c|c|c|}
\hline \multirow{3}{*}{ Variables } & & \multicolumn{4}{|c|}{ Arcoverde } & \multicolumn{4}{|c|}{ Pedra } \\
\hline & & \multicolumn{2}{|c|}{ Stratified } & \multicolumn{2}{|c|}{ Destratified } & \multicolumn{2}{|c|}{ Stratified } & \multicolumn{2}{|c|}{ Destratified } \\
\hline & & Nov 07 & Feb 08 & May 08 & Aug 08 & Nov 07 & Feb 08 & May 08 & Aug 08 \\
\hline Euphotic zone (m) & & 1.2 & 1.4 & 1.5 & 3.1 & 1.2 & 1.1 & 0.9 & 1.9 \\
\hline Mixture zone (m) & & 5.0 & 1.0 & 22.0 & 19.4 & 3.0 & 1.5 & 13.7 & 16.5 \\
\hline Maximal depth (m) & & 12.5 & 11.0 & 22.0 & 19.4 & 11.0 & 10.0 & 13.7 & 16.5 \\
\hline \multirow[t]{2}{*}{ Water temperature $\left({ }^{\circ} \mathrm{C}\right)$} & $\mathrm{S}$ & 26.7 & 30.3 & 28.5 & 24.1 & 24.6 & 26.5 & 27.5 & 24.0 \\
\hline & $\mathrm{B}$ & 23.9 & 25.4 & 28.0 & 23.6 & 23.2 & 24.2 & 27.0 & 23.2 \\
\hline \multirow[t]{2}{*}{ Dissolved oxygen (mg.L ${ }^{-1}$ ) } & $\mathrm{S}$ & 3.0 & 9.2 & 1.2 & 4.0 & 0.6 & 7.1 & 1.9 & 4.6 \\
\hline & $\mathrm{B}$ & 0.1 & 0.1 & 0.7 & 2.3 & 0.1 & 0.1 & 0.5 & 0.1 \\
\hline \multirow[t]{2}{*}{$\mathrm{pH}$} & $\mathrm{S}$ & 8.7 & 7.7 & 6.8 & 7.1 & 8.2 & 7.3 & 8.0 & 6.5 \\
\hline & $\mathrm{B}$ & 7.8 & 7.5 & 6.9 & 7.3 & 7.3 & 7.4 & 7.1 & 6.7 \\
\hline \multirow[t]{2}{*}{ Turbidity (NTU) } & $\mathrm{S}$ & 63.0 & 43.1 & 50.0 & 8.2 & 65.0 & 90.0 & 84.0 & 27.4 \\
\hline & $\mathrm{B}$ & 18.8 & 35.3 & 43.7 & 6.8 & 52.0 & 51.0 & 109.0 & 18.8 \\
\hline \multirow[t]{2}{*}{ Total phosphorus ( $\mu \mathrm{mol})$} & $\mathrm{S}$ & 1.8 & 3.3 & 32.5 & 1.8 & 2.5 & 6.3 & 27.9 & 4.1 \\
\hline & $\mathrm{B}$ & 2.4 & 7.1 & 40.5 & 2.3 & 4.0 & 8.6 & 25.8 & 8.0 \\
\hline \multirow[t]{2}{*}{ Total dissolved phosphorus $(\mu \mathrm{mol})$} & $\mathrm{S}$ & 0.9 & 1.2 & 12.5 & 0.2 & 1.4 & 1.5 & 2.5 & 0.8 \\
\hline & $\mathrm{B}$ & 1.2 & 3.7 & 9.9 & 0.4 & 1.8 & 2.2 & 6.8 & 3.3 \\
\hline \multirow[t]{2}{*}{ Orthophosphate $(\mu \mathrm{mol})$} & $\mathrm{S}$ & 0.4 & 0.3 & 16.8 & 1.5 & 0.5 & 0.2 & 10.4 & 3.3 \\
\hline & $\mathrm{B}$ & 1.0 & 2.2 & 18.3 & 1.8 & 1.1 & 0.9 & 10.8 & 4.7 \\
\hline \multirow[t]{2}{*}{ Total nitrogen $(\mu \mathrm{mol})$} & $\mathrm{S}$ & 1.0 & 1.1 & 0.9 & 1.1 & 0.4 & 0.7 & 0.9 & 1.5 \\
\hline & $\mathrm{B}$ & 0.9 & 0.8 & 1.5 & 6.5 & 0.6 & 1.0 & 0.8 & 14.2 \\
\hline \multirow[t]{2}{*}{$\mathrm{N}: \mathrm{P}$ ratio } & $\mathrm{S}$ & 0.5 & 0.3 & 0.0 & 0.6 & 0.2 & 0.1 & 0.0 & 0.4 \\
\hline & $\mathrm{B}$ & 0.4 & 0.1 & 0.0 & 2.8 & 0.1 & 0.1 & 0.0 & 1.8 \\
\hline Trophic state index & & 60.8 & 70.0 & 85.6 & 63.7 & 58.0 & 62.6 & 84.6 & 53.5 \\
\hline
\end{tabular}




\begin{tabular}{|c|c|c|c|c|c|c|c|c|c|c|}
\hline & & $\infty$ & & $1 \mid+1+1 \stackrel{\infty}{0}+\overrightarrow{0}$ & 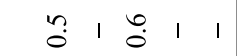 & & 1 & 1 & $\stackrel{\infty}{\circ}$ & 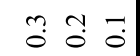 \\
\hline$\ddot{\bar{\theta}}$ & 竧 & $\sum_{4}^{\infty 0}$ & & $1++1+1 \tilde{0}: \overrightarrow{0}$ & $\begin{array}{lllll}\infty & n & n & 1 & 1\end{array}$ & & 1 & 1 & $\bar{\sigma}$ & 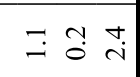 \\
\hline  & 焉 & $\infty$ & & $1+11++\exists 11$ & $+1 \stackrel{0}{m} \quad 1 \quad 1$ & & 1 & 1 & $\tilde{0}$ & $\stackrel{m}{o}+\stackrel{o}{+}$ \\
\hline & & $\sum_{i}^{\pi}$ is & & $++++++\tilde{0}_{0} \mid 1$ & $+1 \stackrel{9}{-} 1+$ & & 1 & 1 & $\stackrel{+}{0}$ & $\stackrel{\infty}{0} \overrightarrow{0} \bar{m}$ \\
\hline 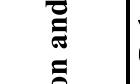 & $\begin{array}{l}\frac{\pi}{3} \\
0 \\
0\end{array}$ & $\left.\infty\right|_{\infty} ^{\infty}$ & & $1++1++\underset{\sim}{-} 1$ & 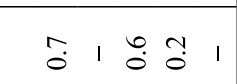 & & 1 & 1 & $\stackrel{\varrho}{0}$ & فे \\
\hline & 起 & 考 & & $1++1+1+301$ & $\begin{array}{lllll}0 & 1 & a & 1 & - \\
0\end{array}$ & & 1 & 1 & $\begin{array}{c}n \\
\ddot{n} \\
m\end{array}$ & aे \\
\hline & 害 & $=m$ & & 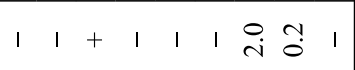 & \begin{tabular}{ll|l|l|}
$n$ & $\infty$ & $\infty$ & 1 \\
0 & 1 & -1
\end{tabular} & & 1 & । & $\hat{b}$ & 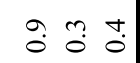 \\
\hline$\overline{0}$ & & 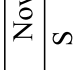 & & $1++11130$ & $=1910$ & & 1 & 1 & $\begin{array}{l}\infty \\
\dot{m} \\
\dot{m}\end{array}$ & $\stackrel{\infty}{i} \tilde{0})$ \\
\hline & & $\infty$ & & $1+1+1+11$ & $\stackrel{\circ}{i}+\stackrel{n}{m}+1$ & & + & + & $\stackrel{\circ}{-}$ & $\stackrel{m}{-} \overrightarrow{0}+$ \\
\hline$\frac{3}{2}$ & . & $\overrightarrow{4}$ in & & $1+11+1+1+$ & $\exists+\stackrel{0}{+}+1$ & & + & $\overrightarrow{0}$ & $\stackrel{\infty}{\infty}$ & $\because$\begin{tabular}{ccc}
$n$ & 0 \\
\hdashline & 0 & 0 \\
\hdashline
\end{tabular} \\
\hline & 焉 & $\infty$ & & $1 \mid+1++\frac{n}{0} 11$ & $\begin{array}{lllll}\pi & \mid & \overrightarrow{0} & \overrightarrow{0} & 1\end{array}$ & & 1 & । & $\ddot{0}$ & $\tilde{0}+\tilde{0}$ \\
\hline & 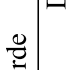 & $\sum_{i}^{\pi}$ is & & $1|1|++\underset{0}{0} 11$ & $\begin{array}{lllll}n & 1 & 1 & 1\end{array}$ & & 1 & 1 &  & $\stackrel{\infty}{-}+\stackrel{?}{0}$ \\
\hline & & $\left.\infty\right|^{\infty}$ & & $+++++1+\tilde{0} 1$ & $+\quad 1 \quad 1 \quad 1+$ & & 1 & 1 & $\stackrel{\circ}{+}$ & $\overrightarrow{0}++$ \\
\hline & : & \begin{tabular}{|l|l}
0 \\
0 \\
0
\end{tabular} & & $1++1+1+11$ & $\begin{array}{lllll}3 & 1 & 1 & 1 & 3 \\
0 & 0\end{array}$ & & 1 & 1 & $\begin{array}{c}m \\
\infty \\
\infty\end{array}$ & $\begin{array}{lll}t & m & 0 \\
0 & 0 & 0\end{array}$ \\
\hline & 傿 & $\approx$ & & $1++1+1 \stackrel{m}{0} \overrightarrow{0} 1$ & $\begin{array}{lllll}0 & 1 & 1 & 1 & 1\end{array}$ & & 1 & । & $\dot{m}$ & กั่ ชุ \\
\hline : & & $\vec{z}$ is & & $1++++1+\tilde{n}_{n} 1$ & 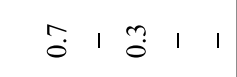 & & 1 & 1 & $\underset{i}{i}$ & $\stackrel{n}{+} \stackrel{0}{0} \stackrel{0}{-}$ \\
\hline 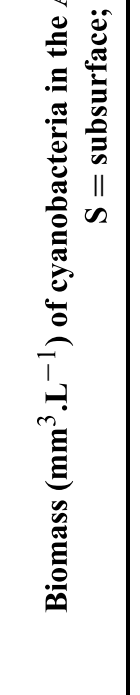 & & 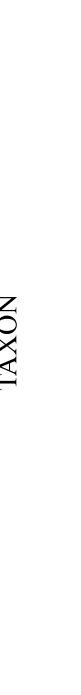 &  & 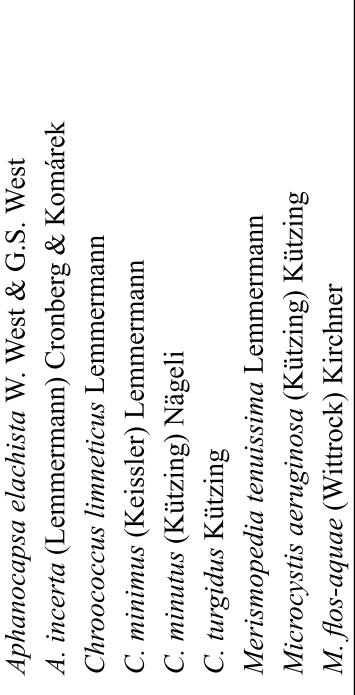 &  & 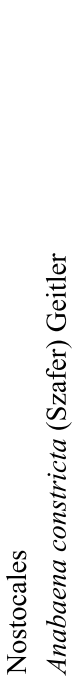 &  & 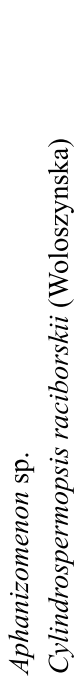 & 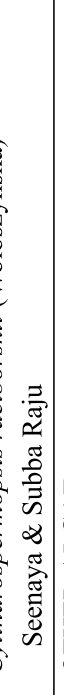 &  \\
\hline
\end{tabular}



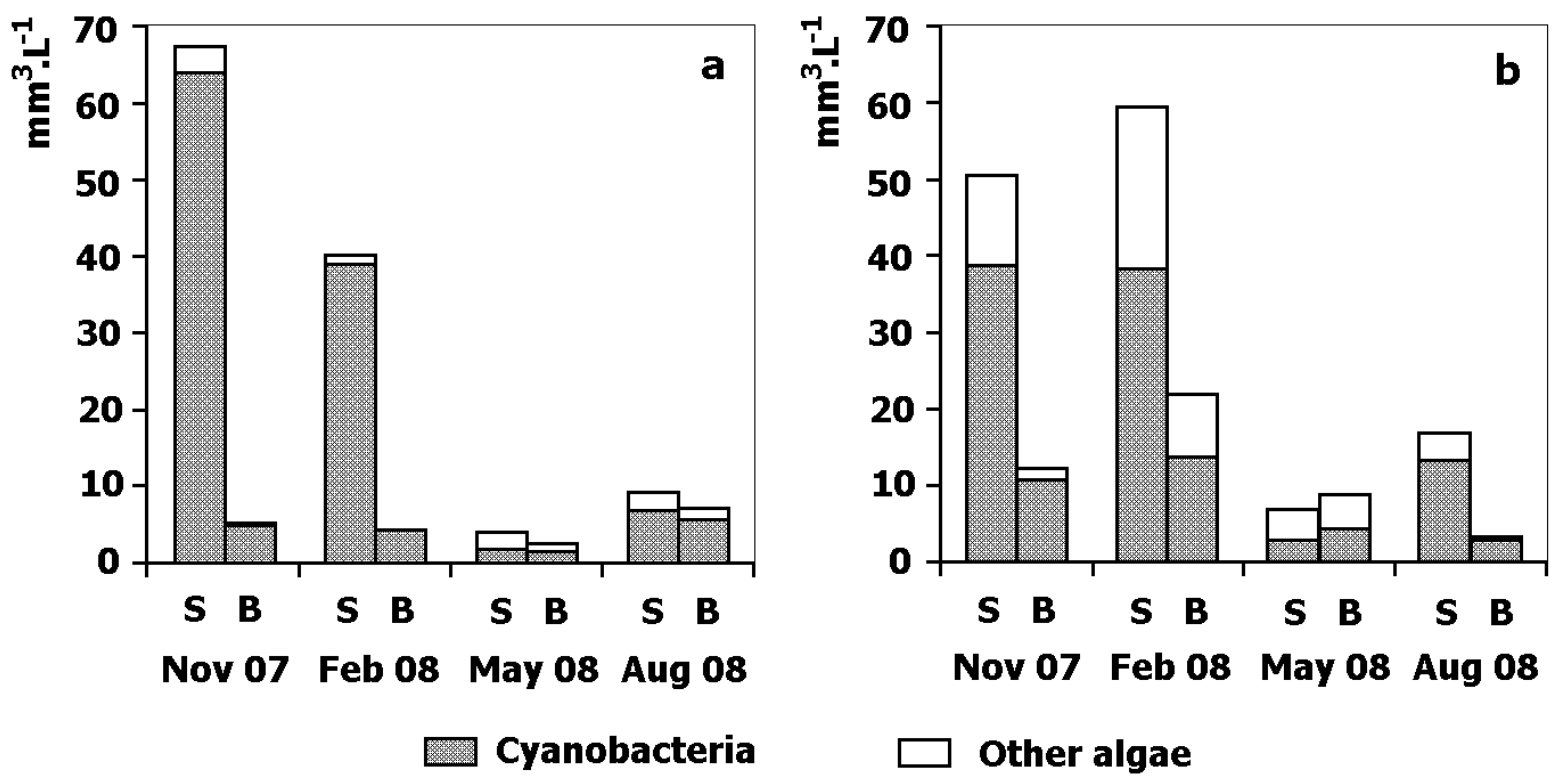

Fig. 3 - Variation in biomass of cyanobacteria and other algae $\left(\mathrm{mm}^{3} . \mathrm{L}^{-1}\right)$ in the Arcoverde (a) and Pedra (b) reservoirs, Pernambuco State, Brazil; $\mathrm{S}=$ subsurface; $\mathrm{B}=$ bottom.
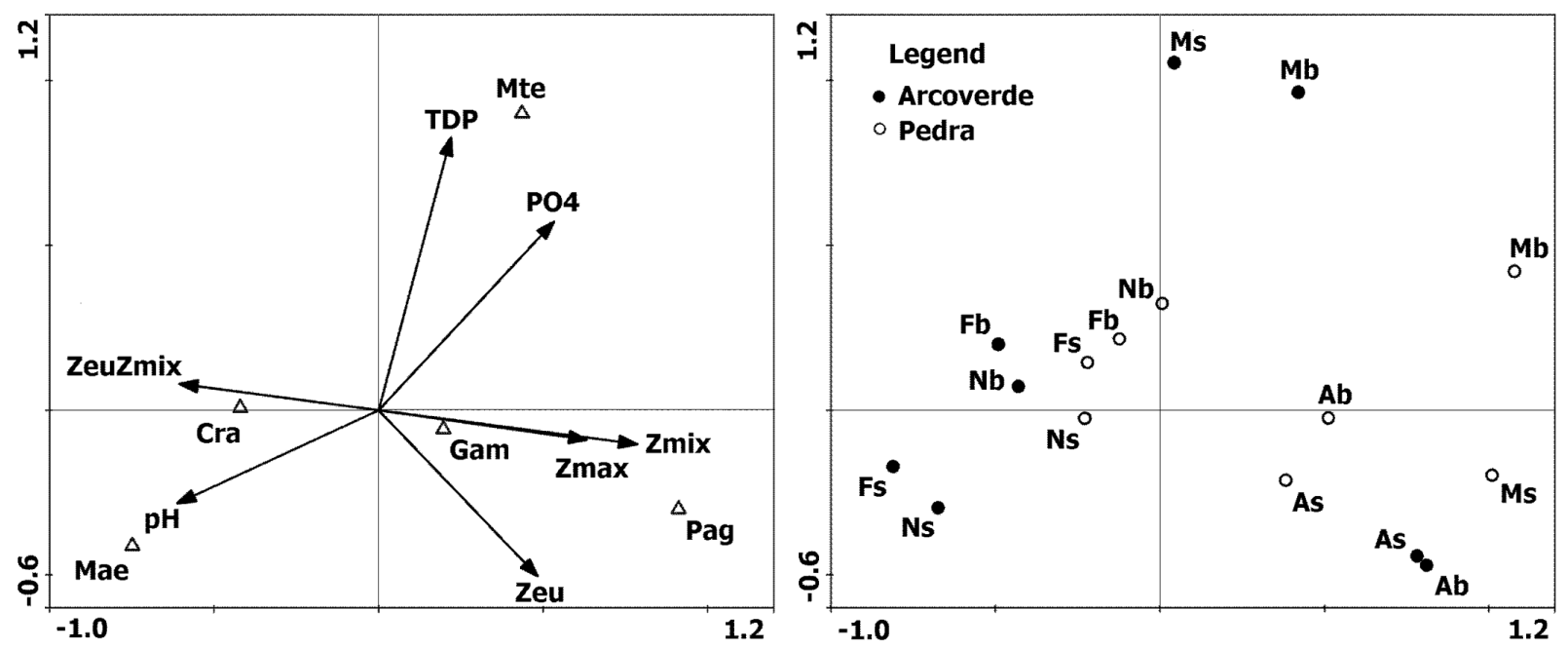

Fig. 4 - CCA performed for the main species of plankton algae and significant abiotic variables in the Arcoverde and Pedra reservoirs, Pernambuco State, Brazil; Cyanobacteria - Cra: Cylindrospermopsis raciborskii; Gam: Geitlerinema amphibium; Mae: Microcystis aeruginosa; Mte: Merismopedia tenuissima; Pag: Planktothrix agardhii; Abiotic variables - PO4: orthophosphate; TDP: total dissolved phosphorus; Zeu: euphotic zone; Zmix: mixture zone; ZeuZmix: euphotic zone/mixture zone ratio; Zmax: maximal depth; Sampling units are identified with the first letter of the month (A: August; F: February; M: May; N: November) and sampling depth (s: subsurface; b: bottom).

period in the Arcoverde reservoir. M. aeruginosa was associated to sampling units from the subsurface, higher $\mathrm{pH}$ values and lower phosphorus content. M. tenuissima was related positively to this axis and associated to sampling units from the bottom at both depths in May and higher phosphorus values (Table III, Fig. 4).

\section{DISCUSSION}

Changes in the phytoplankton structure in tropical and subtropical eutrophic ecosystems are predominantly related to thermal variations (Marinho and Huszar 2002, Heo and Kim 2004, Becker et al. 2006, Pennard et al. 
TABLE III

Statistical summary and correlation coefficients for phytoplankton species and abiotic variables on the first two CCA axes for the Arcoverde and Pedra reservoirs, Pernambuco State, Brazil.

\begin{tabular}{|c|c|c|c|c|}
\hline \multicolumn{3}{|l|}{  } & Axis 1 & Axis 2 \\
\hline \multicolumn{3}{|l|}{ Eigenvalues } & 0.310 & 0.109 \\
\hline \multicolumn{3}{|c|}{ Accumulated variance in biotic data $(\%)$} & 53.4 & 72.3 \\
\hline \multicolumn{3}{|c|}{ Accumulated variance in } & & \\
\hline \multicolumn{3}{|c|}{ species-environment relation $(\%)$} & 61.8 & 83.7 \\
\hline \multicolumn{3}{|c|}{ Species-environment correlation } & 0.991 & 0.872 \\
\hline \multicolumn{5}{|c|}{ Monte Carlo test } \\
\hline \multicolumn{3}{|c|}{ Significance of first canonical axis $-p$} & & 0.001 \\
\hline \multicolumn{3}{|c|}{ Significance of all canonical axes $-p$} & & 0.001 \\
\hline \multirow[b]{3}{*}{ Mixture zone (Zmix) } & \multicolumn{2}{|c|}{ Canonical coefficient } & \multicolumn{2}{|c|}{ Intra-set correlation } \\
\hline & Axis 1 & Axis 2 & Axis 1 & Axis 2 \\
\hline & 0.78 & -0.09 & 0.79 & -0.10 \\
\hline Euphotic zone (Zeu) & 0.48 & -0.44 & 0.49 & -0.50 \\
\hline Zeu:Zmix ratio & -0.60 & 0.07 & -0.61 & 0.08 \\
\hline Maximal depth & 0.63 & -0.08 & 0.64 & -0.09 \\
\hline $\mathrm{Ph}$ & -0.61 & -0.25 & -0.61 & -0.28 \\
\hline Total dissolved phosphorus & 0.22 & 0.72 & 0.22 & 0.83 \\
\hline Orthophosphate & 0.53 & 0.50 & 0.53 & 0.57 \\
\hline
\end{tabular}

2008). The studies cited report that cyanobacteria have higher biomasses in periods of thermal stratification and are replaced by diatoms under conditions of thermal circulation. However, this is not a rule, as there are reports of cases in which cyanobacteria dominate the environment throughout the year (Crossetti and Bicudo 2008, Soares et al. 2009a). In such cases, the seasonal substitution of species of cyanobacteria occurs, with high biomass values of colonial organisms during periods of thermal stratification and filamentous cyanobacteria during the destratification phase. Nonetheless, colonial taxa form blooms under mixture conditions, and filamentous taxa occur during stratification. In ecosystems in northeastern Brazil, the dominance of a single species throughout the year has been recorded, with oscillating biomass values that may be related to variations in temperature or thermal pattern (Bouvy et al. 1999, Huszar et al. 2000, Dantas et al. 2008).

In the present study, cyanobacteria were predominant in the two eutrophic reservoirs in the semi-arid region of northeastern Brazil, regardless of the thermal condition. Greater biomasses were found under conditions of stratification, with the dominance of a single species. During periods of destratification, the structure of the phytoplankton community was formed by different species. Other algal divisions coexisted with the cyanobacteria, especially diatoms and phytoflagellates, particularly during periods of the thermal instability.

Destratification affects the availability of light and input of nutrients from the sediment (Mischke 2003). Unfavorable light conditions are disadvantageous for organisms that are obligatorily phototrophic and advantageous for mixotrophic organisms (O'Farrell et al. 2003). During the period of destratification (rainy season) in the ecosystems studied, there was an increase in the euphotic zone and a reduction in the availability of light in the water column. This facilitated the development of phytoflagellates and diatoms, which certainly competed for the niche with the cyanobacteria.

The biomass of species and composition of the community vary under conditions of stratification and destratification (Crossetti and Bicudo 2008, Dantas et al. 2008, Soares et al. 2009a, Bittencourt-Oliveira et al. 2011). In the reservoirs studied, C. raciborskii dominated during stratification, with biomasses above 3.9 $\mathrm{mm}^{3} \cdot \mathrm{L}^{-1}$. During destratification, this organism was 
replaced by $P$. agardhii, the biomass of which did not surpass $5.5 \mathrm{~mm}^{3} \cdot \mathrm{L}^{-1}$. G. amphibium and M. tenuissima exhibited greater relative abundance during thermal destratification, coexisting with P. agardhii and $C$. raciborskii.

The dominance of $C$. raciborskii occurs in strongly stratified ecosystems with a high degree of intermittence in the availability of nutrients (Bouvy et al. 2000, Marinho and Huszar 2002, Bormans et al. 2005). Although stratification was not found in other reservoirs in the semi-arid region of northeastern Brazil (Bouvy et al. 1999, Huszar et al. 2000, Chellappa and Costa 2003, von Sperling et al. 2008), the authors cited report the dominance of this species in periods with lower concentrations of nutrients, especially nitrogen. This occurs because $C$. raciborskii is able to store phosphorus and synthesize nitrogen, regardless of the thermal conditions.

Borics et al. (2000) report the replacement of $C$. raciborskii by $P$. agardhii, with the disappearance of $C$. raciborskii accompanied by reductions in water temperature, biomass of the community and abundance of the cyanobacteria P. agardhii and Pseudanabaena limnetica (Lemmermann) Komárek. Fonseca and Bicudo (2008) report the dominance of Raphidiopsis/Cylindrospermopis under conditions of stratification, with the biomass of these taxa gradually reduced during destratification and the subsequent coexistence with other cyanobacteria, diatoms and chlorophytes.

Thermal stratification leads to the establishment of high biomasses of cyanobacteria (Marinho and Huszar 2002, Soares et al. 2009a), whereas destratification is related to a change in the algal structure, with the replacement of cyanobacteria by other groups of algae (Tundisi 1990, Naselli-Flores and Barone 1998, Heo and Kim 2004, Becker et al. 2006) or other species of cyanobacteria (Crossetti and Bicudo 2008, Soares et al. 2009a). However, this is not a rule, as high biomasses of cyanobacteria also occur during the mixture period (Bouvy et al. 1999, 2001, Figueredo and Giani 2009, Soares et al. 2009b).

In conclusion, the dynamics of these deep, eutrophic reservoirs in the semi-arid region of northeastern Brazil were influenced by the thermal pattern, with the structure of the algal community, behavior of the euphotic zone and availability of nutrients being similar during the period of thermal stratification. While stratification determined the dominance and high biomass of C. raciborskii, destratification hindered the formation of blooms and increased the competition among species. Despite the reduction in algal biomass during the period of destratification, the cyanobacteria were not replaced by other divisions and remained dominant throughout the year. Thermal changes in the water column caused by climatologic events alter other physiochemical conditions of the water, leading to changes in the composition and biomass of the cyanobacterial community in tropical reservoirs.

\section{RESUMO}

Este estudo investigou a dinâmica das cianobactérias em dois reservatórios eutróficos e profundos localizados na região semi-árida do Brasil durante períodos de estratificação e desestratificação térmica. Quatro coletas foram feitas em cada reservatório em duas profundidades em intervalo de três meses. As variáveis abióticas analisadas foram: temperatura da água, oxigênio dissolvido, $\mathrm{pH}$, turbidez, transparência da água, fósforo total, fósforo total dissolvido, ortofosfato e nitrogênio total. A densidade do fitoplâncton foi quantificada para a determinação da biomassa de cianobactérias. Os dados foram analisados usando ACC. Elevados valores médios de biomassa fitoplanctônica $\left(29,8 \mathrm{~mm}^{3} . \mathrm{L}^{-1}\right)$ ocorreram no período de estratificação. A maior similaridade das comunidades fitoplanctônicas também ocorreu neste período e foi relacionada ao desenvolvimento de cianobactérias, principalmente Cylindrospermopsis raciborskii $\left(>3,9 \mathrm{~mm}^{3} \cdot \mathrm{L}^{-1}\right)$. Durante o período de desestratificação térmica, esta espécie co-dominou o ambiente com Planktothrix agardhii, Geitlerinema amphibium, Microcystis aeruginosa e Merismopedia tenuissima, bem como com diatomáceas e fitoflagelados. Instabilidade ambiental e competição entre as algas dificultaram o estabelecimento de blooms durante o período de mistura quando comparado com o período de estratificação. Modificações na condição térmica da coluna d'água, causadas por eventos climatológicos, alteraram as demais condições fisicoquímicas da água e ocasionaram mudanças na composição e biomassa da comunidade de cianobactérias em reservatórios tropicais.

Palavras-chave: biomassa, Cylindrospermopsis raciborskii, dinâmica sazonal, padrão térmico. 


\section{REFERENCES}

ANTENUCCI JP, GHADOUANi A, BURFORD MA AND ROMERO JR. 2005. The long-term effect on artificial destratification on phytoplankton species composition in a subtropical reservoir. Freshw Biol 50: 1081-1093.

Becker A, Herschel A ANd Wilhelm C. 2006. Biological effects of incomplete destratification of hypertrophic freshwater reservoir. Hydrobiologia 559: 85-100.

Becker V, Huszar VLM and Crossetti LO. 2009. Responses of phytoplankton functional groups to the mixing regime in a deep subtropical reservoir. Hydrobiologia 628: $137-151$.

Benhardt J, Elliott JA AND Jones ID. 2008. Modelling the effects on phytoplankton communities of changing mixed depth and background extinction coefficient on three contrasting lakes in the English Lake District. Freshw Biol 53: 2573-2586.

Bicudo CEM And Menezes M. 2006. Gêneros de algas de águas continentais do Brasil: chave para identificação e descrições. $2^{\text {nd }}$ ed., São Carlos: Rima, 508 p.

Bittencourt-Oliveira MC, Moura AN, Hereman TC AND DANTAS EW. 2011. Increase in straight and coiled Cylindrospermopsis raciborskii (Cyanobacteria) populations under conditions of thermal destratification in a shallow tropical reservoir. J Water Resour Prot 3: $245-252$.

Borics G, Grigorszky I, Szabó S AND PAdisák J. 2000. Phytoplankton associations in a small hypertrophic fishpond in East Hungary during a change from bottomup to top-down control. Hydrobiologia 424: 79-90.

Bormans M, Ford PW AND FABbro L. 2005. Spatial and temporal variability in cyanobacterial populations controlled by physical processes. J Plankton Res 27(1): 6170 .

Bouvy MA, Falcão D, Marinho M, PAgano M AND MOURA A. 2000. Occurrence of Cylindrospermopsis (Cyanobacteria) in 39 Brazilian tropical reservoirs during the 1998 drought. Aquat Microb Ecol 23: 13-27.

Bouvy M, Molica R, De Oliveira S, Marinho M AND BECKER B. 1999. Dynamics of a toxic cyanobacterial bloom (Cylindrospermopsis raciborskii) in a shallow reservoir in the semi-arid region of northeast Brazil. Aquat Microb Ecol 20(3): 285-297.

Bouvy MA, Molica R, Oliveira S, Marinho M AND BECKER B. 2001. Effects of a cyanobacterial bloom (Cylindrospermopsis raciborskii) on bacteria and zooplankton communities in Ingazeira reservoir (northeast Brazil). Aquat Microb Ecol 25(3): 215-227.
Briand JF, Leboulanger C, Humbert J, Bernard C AND DUFOUR P. 2004. Cylindrospermopsis raciborskii (Cyanobacteria) invasion at mid-latitudes: selection, wide physiological tolerance, or global warming? J Phycol 40: 231-238.

Briand JF, Robillot C, QUiblier-Lloberas C, Humbert JF, Couté A And Bernard C. 2002. Environmental context of Cylindrospermopsis raciborskii (Cyanobacteria) blooms in a shallow pond in France. Water Res 36: 3183-3192.

Burford MA AND O’Donohue MJ. 2006. Comparison of phytoplankton community assemblages in artificially and naturally mixed subtropical water reservoirs. Freshw Biol 51: 973-982.

Calijuri MC, Dos Santos ACA and Jati S. 2002. Temporal changes in the phytoplankton community structure in a tropical and eutrophic reservoir (Barra Bonita, SP, Brazil). J Plankton Res 24(7): 617-634.

Caraco NF AND Miller R. 1998. Effects of $\mathrm{CO}_{2}$ on competition between a cyanobacterium and eukaryotic phytoplankton. Can J Fish Aquat Sci 55: 54-62.

CARLSON RE. 1977. A trophic state index for lakes. Limnol Oceanogr 22(2): 361-369.

Chellappa NT, Chellappa SL and Chellappa S. 2008. Harmful phytoplankton blooms and fish mortality in a eutrophicated reservoir of Northeast Brazil. Braz Arch Biol Technol 51(4): 833-841.

Chellappa NT And Costa MAM. 2003. Dominant and co-existing epecies of Cyanobacteria from a eutrophicated reservoir of Rio Grande do Norte State, Brazil. Acta Oecol 24: S3-S10.

Chen X, Wang X, Wu D, He S, Kong H and Kawabata Z. 2009. Seasonal variation of mixing depth and its influence on phytoplankton dynamics in the Zeya reservoir, China. Limnology 10: 159-165.

Cole GA. 1994. Textbook of limnology. $4^{\text {th }}$ ed., Long Grove: Waveland Press, $412 \mathrm{p}$.

Crossetti LO And Bicudo CEM. 2008. Adaptations in phytoplankton life strategies to improsed change in shallow urban tropical eutrophic reservoir, Garças Reservoir, over 8 years. Hydrobiologia 614: 91-105.

Dantas EW, Moura AN, Bittencourt-Oliveira MC, ArRuda-Neto JDT AND CAVAlCANTI ADC. 2008. Temporal variation of the phytoplankton community at short sampling intervals in the Mundaú reservoir, Northeastern Brazil. Acta Bot Brasil 22(4): 970-982.

Downing JA AND MCCAUley E. 1992. The nitrogen: phosphorus relationship in lakes. Limnol Oceanogr 37: 936-945. 
Figueredo CC And Giani A. 2009. Phytoplankton community in the tropical lake of Lagoa Santa (Brazil): Conditions favoring a persistent bloom of Cylindrospermopsis raciboskii. Limnologica 39: 264-272.

FonseCA BM AND Bicudo CEM. 2008. Phytoplankton seasonal variation in a shallow stratified eutrophic reservoir (Garças Pond, Brazil). Hydrobiologia 600: 267-282.

HeO W AND KIM B. 2004. The effect of artificial destratification on phytoplankton in a reservoir. Hydrobiologia 524: 229-239.

Hillebrand H, Dürselen C, Kirschtel D, PollinGHER U AND ZOHARY T. 1999. Biovolume calculation for pelagic and benthic microalgae. J Phycol 35: 403-424.

Huszar VlM, Silva LHS, Marinho M, Domingos P AND SANT'ANNA CL. 2000. Cyanoprokaryote assemblages in eight productive tropical Brazilian waters. Hydrobiologia 424: 67-77.

KomÁReK J AND ANAgnostidis K. 1989. Modern approach to the classification system of Cyanophytes, 4: Nostocales. Algol Stud 56: 247-345.

KomÁrek J And Anagnostidis K. 1999. Cyanoprokayota 1. In: EtTl H, Gartner G, HeYNing H AND Mollenhauer D (Eds), Chroococcales. Stutgart: Subwasserflora von Mitteleuropa. Gustav Fischer, 548 p.

KomÁrek J AND ANAgnostidis K. 2005. Cyanoprokayota 2. In: Bridel B, KRIENitz L, GARTNER G AND SCHARGERL M (Eds), Oscillatoriales. Müncher: Subwasserflora von Mitteleuropa. Elsevier GmbH, 759 p.

Komárek J And Cronberg G. 2001. Some Chroococcalean and Oscilatorialen Cyanoprokaryotes from southern African lakes, ponds and pools. Nova Hedwigia 73: 129-160.

Kosten S, Huszar VlM, Mazzeo N, Scheffer M, Sternberg LSL AND JePpesen E. 2009. Ecol Appl 19: 1791-1804.

MARINHO MM AND AZEvedo SMFO. 2007. Influence of $\mathrm{N} / \mathrm{P}$ ratio on competitive abilities for nitrogen and phosphorus by Microcystis aeruginosa and Aulacoseira distans. Aquat Ecol 41: 525-533.

MARINHo MM AND Huszar VLM. 2002. Nutrient availability and physical conditions as controlling factors of phytoplankton composition and biomass in a tropical reservoir (Southeastern Brazil). Arch Hydrobiol 153(3): 443-468.

Melo-Júnior M, Almeida Vls, Paranaguá MN AND Moura AN. 2007. Crustáceos planctônicos de um reservatório oligotrófico do Nordeste do Brasil. Rev Brasil Zoocienc 9(1): 19-30.
MischKe U. 2003. Cyanobacteria associations in shallow polytrophic lakes: influence of environmental factors. Acta Oecol 24: s11-s23.

Moura AN, Bittencourt-Oliveira MC, Dantas EW AND ARrudA-Neto JDT. 2007a. Phytoplanktonic Associations: A Tool to Understand Dominance Events in a Tropical Brazilian Reservoir. Acta Bot Brasil 21(3): 641-648.

Moura AN, Dantas EW And BitTencourt-Oliveira MC. 2007b. Structure of the phytoplankton in a water supply system in the state of Pernambuco - Brazil. Braz Arch Biol Technol 50(4): 645-654.

NAselli-Flores L And BARONe R. 1998. Phytoplankton dynamics in two reservoirs with different trophic state (Lake Rosamarina and Lake Arancio, Sicily, Italy). Hydrobiologia 369/370: 163-178.

NiKLISCH A AND KoHL JG. 1989. The influence of light on the primary production of two planktic blue-green algae. Arch Hydrobiol, Ergeb Limnol 33: 451-455.

O'FARrell I, Sinistro R, IzAGUiRre I AND UNREIN F. 2003. Do steady state assemblages occur in shallow lentic environments from wetlands? Hydrobiologia 502: 197209.

Paerl HW And Huisman J. 2008. Blooms like it hot. Science 320: 57-58.

Pennard A, Bormans M and Lagadeuc Y. 2008. Phytoplankton species turnover controlled by physical forcing at different time scales. Can J Fish Aquat Sci 65: $47-60$.

ReynOLDS CS. 1999. Non-determinism to Probability, or $\mathrm{N}: \mathrm{P}$ in the community ecology of phytoplankton. Arch Hydrobiol 146: 23-35.

REYNOLDS CS AND WALSBY AE. 1975. Water blooms. Biol Rev 50: 437-481.

SAKER ML AND GRIFFITHS DJ. 2001. Occurrence of blooms of the cyanobacterium Cylindrospermopsis raciborskii (Woloszynska) Seenayya and Subba Raju in a north Queensland domestic water supply. Mar Freshw Res 52: 907-915.

SHAPIRO J. 1990. Current beliefs regarding dominance of blue-greens: the case for importance of $\mathrm{CO}_{2}$ and $\mathrm{pH}$. Verh Int Ver Theor Angew Limnol 24: 38-54.

SMITH VH. 1983. Low nitrogen to phosphorus ratios favor dominance by blue-green algae in lake phytoplankton. Science 221: 669-671.

SoARes MCS, Rocha MIA, Marinho MM, AzEVEdo AMFO, BRANCO CWC AND Huszar VLM. 2009a. Changes in species composition during annual cyanobac- 
terial dominance in a tropical reservoir: physical factors, nutrients and grazing effects. Aquat Microb Ecol 57: $137-149$.

SoARES MCS, Vidal LO, Roland F AND Huszar VLM. 2009b. Cyanobacterial equilibrium phases in a small tropical impoundment. J Plankton Res 31: 1331-1338.

SRH - Secretaria de Recursos Hídricos De PerNAMBUCO. 2000. Plano Estadual de Recursos Hídricos do Estado de Pernambuco - Documento Síntese, Recife.

STRICKLAND JD AND PARSONS TR. 1965. A manual of sea water analysis. Bull Fish Res Board Can 125: 1-185.

TUNDISI JG. 1990. Perspectives for ecological modeling of tropical and subtropical reservoirs in South America. Ecol Model 52(1/2): 7-20.

UTERMÖHL H. 1958. Zur vervollkommer der quantitativen phytoplankton methodik. Mitt Int Ver Theor Angew Limnol 9: 1-38.
VALDERRAMA GC. 1981. The simultaneous analysis of total nitrogen and total phosphorus in natural waters. Mar Chem 10: 109-122.

Von Sperling EV, Ferreira ACS and Gomes LNL. 2008. Comparative eutrophication development in two Brazilian water supply reservoirs with respect to nutrient concentrations and bacteria growth. Desalination 226: $169-174$.

Walsby AE, Hayes PK, Boje R and Stal L. 1997. The selective advantage of buoyancy provided by gas vesicles for planktonic cyanobacteria in the Baltic Sea. New Phytol 136: 407-417.

Watson SB, McCauley E and Downing JA. 1997. Patterns in phytoplankton taxonomic composition across temperate lakes of differing nutrient status. Limnol Oceanogr 42: 487-495. 